\title{
Physicochemical Characterization of Dioscorea spp. in Manokwari Regency, West Papua
}

\author{
Paulus Chadikun ${ }^{1,3, *}$, Amalia Tetrani Sakya ${ }^{2}$, Vita Ratri Cahyani ${ }^{2}$, \\ Maria Theresia Sri Budiastuti ${ }^{2}$
}

\author{
${ }^{1}$ Postgraduate Program, Sebelas Maret University, Surakarta, Indonesia \\ ${ }^{2}$ Faculty of Agriculture, Sebelas Maret University, Surakarta, Indonesia \\ ${ }^{3}$ Faculty of Agriculture, University of Papua, Manokwari, 98314, Indonesia \\ ${ }^{*}$ Corresponden Author, e-mail: chadikunpaulus@gmail.com
}

\begin{abstract}
Dioscorea spp is a wild plant which is an important food source, however there are no published studies on the nutritional composition of this plants growing at Manokwari Regency. Physical analysis includes color testing using the brand Minolta Reflectance Chromameter type CR-300. Chemical analysis includes HCN content, proximate composition, and crude fiber determining based on AOAC standard methods. The results of the physicochemical characterization of tubers in four species of Dioscorea spp explorated in Manokwari Regency showed that their variations influenced by genetic difference, soil fertility, location, and plant age.

Keywords: Dioscorea spp, Physicochemical, Manokwari
\end{abstract}

\section{INTRODUCTION}

Yam (Dioscorea spp) is an annual shrubs that propagate from the Dioscoreaceae family. This family consists of about 650 species, 10 of which can be consumed, distributed either in the tropical and subtropical regions, which are included in dioecious plants, growing wrapped around and creep, with large, single or clustered tubers $[1,2]$.

Species belonging to the genus Dioscorea (yam) may have originated in Southeast Asia [3]. The species diversity of this plant on the three separate continents due to its evolution differences as a result of the formation of the Atlantic Ocean and the drying up of the Middle East [4]. As a result, the diversity of the main species arose in the three centers: West Africa, Southeast Asia and Tropical America [5].

Dioscorea spp. is the third most important tuber crop after cassava and sweet potato in West Africa, Central America, the Caribbean, Pacific Islands and Southeast Asia [6]. According to [7], yam (6\%), is included among the top five food crop species contributing $99 \%$ of the world production, and ranks number four in the world after potatoes (46\%), cassava (28\%), cassava (28\%) 18\%), followed by types of taro (1\%).

Tubers are important source of carbohydrates as a major source of energy and food in the tropical and subtropical countries [8]. Various forms and cultivars of wild edible yam species can be found in different places with different nutritional value and composition. The composition of wild yam tubers is not widely known and that is the reason to expect that some wild species have different compositions than cultivated varieties [9].

Moreover, yam (Dioscorea spp.) is a wild plant which is an important and best food source for our knowledge, but there are no published studies on the nutritional composition of this plants originated from Manokwari Regency. Therefore, the purpose of this research was to do the physicochemical characterization of yam tubers (Dioscorea spp) explorated in Manokwari Regency, West Papua Province.

\section{MATERIALS AND METHODS}

\section{a. Sample Eploration and Preparation}

The exploration in Manokwari Regency was successfully obtained 40 accessions of wild yam (Dioscorea spp.) which consisted of 8 plants of Dioscorea bulbifera L., 7 Dioscorea pentaphylla L., 3 Dioscorea alata L. and 1 Dioscorea hispida Dennst. The explorated tubers were wrapped immediately by newspaper in the field without being cleaned or washed and stored between 3-4 days at room temperature. By the time of shipment preparation, the tuber samples were then cleaned, washed, dried by tissue paper and wrapped by straw paper then put in plastic bag. The tubers were then analyzed at Laboratory of the Center for Research and Development of Postharvest Agriculture, Agricultural Research and Development Agency, Ministry of Agriculture, Bogor. 


\section{b. Sample Preparation}

The tuber sample preparation was carried out by peeling the tuber without being washed and then cut off part of the tuber flesh for colour testing and partly mashed for HCN content analyses. Other tuber samples were washed and mashed after being peeled to analyze the content of proximat and crude fiber.

\section{c. Physical Analysis}

Physical analysis includes testing the color immediately after the preparation is complete. The color testing was conducted by inserting the sample pieces into a plastic cup, then covered with black cardboard. The sensor tool then attached to the mouth of the cup, before the power button on the device is turned on. Test results that are legible were then recorded. The color test included the value of $\mathrm{L}$ which is the brightness level of the sample, a is the difference between red and green (red: + ; green: -), and b is the difference between yellow and blue (yellow: +; blue: -) by using the brand of Minolta Reflectance Chromameter CR type CR-300, while the value of $\Delta \mathrm{E}$ is the total color difference obtained from the formula $\sqrt{\left(L^{2}+a^{2}+b^{2}\right)}$.

\section{d. Chemical Analysis}

Chemical analysis included analysis content of HCN [10], water, ash, fat, protein, crude fiber [11], and carbohydrates by various methods.

\section{RESULTS AND DISCUSSION}

Physicochemical analysis of yam tuber (Dioscorea spp.) explorated in Manokwari Regency, West Papua Province is shown in Table 1 and Table 2. Variations were found in the analysis results of both physical and chemical characteristics between the tubers of yam plants.

Table 1. The characteristic of Dioscorea spp tuber colour based on fresh weight

\begin{tabular}{|l|c|c|c|c|}
\hline \multirow{2}{*}{ Spesies } & \multicolumn{3}{|c|}{ Hunter Scale } & \multirow{2}{*}{$\Delta \mathbf{E}$} \\
\cline { 2 - 4 } & $\mathbf{L}^{*}$ & $\mathbf{a}^{*}$ & $\mathbf{b}^{*}$ & 77.75 \\
\hline Dioscorea bulbifera L. & 73.64 & 1.96 & 23.25 & 69.86 \\
\hline Dioscorea pentaphylla L. & 69.55 & 0.78 & 5.50 & 69.99 \\
\hline Dioscorea alata L. & 68.41 & 4.53 & 9.30 & 75.70 \\
\hline Dioscorea hispida Dennst & 67.59 & -2.02 & 34.04 & \\
\hline
\end{tabular}

Table 2. Chemical characteristic of Dioscorea spp. tuber based on fresh weight

\begin{tabular}{|l|c|c|c|c|}
\hline \multicolumn{1}{|c|}{ Parameter } & $\begin{array}{c}\text { Dioscorea } \\
\text { bulbifera } \mathbf{L} .\end{array}$ & $\begin{array}{c}\text { Dioscorea } \\
\text { pentaphylla } \mathbf{L .}\end{array}$ & $\begin{array}{c}\text { Dioscorea } \\
\text { alata } \mathbf{L} .\end{array}$ & $\begin{array}{c}\text { Dioscorea hispida } \\
\text { Dennst. }\end{array}$ \\
\hline Moisture Content (\%) & 82,76 & 85,69 & 78,18 & 76,43 \\
\hline Ash Content (\%) & 0,62 & 0,62 & 0,63 & 1,02 \\
\hline Fat Content (\%) & 0,13 & 0,14 & 0,13 & 0,14 \\
\hline Protein Content (\%) & 1,80 & 1,69 & 1,57 & 3,85 \\
\hline Carbohidrate Content (\%) & 14,69 & 11,86 & 19,48 & 18,56 \\
\hline Crude Fiber Content (\%) & 0,63 & 1,28 & 1,25 & 0,43 \\
\hline HCN (ppm) & 31,04 & 39,80 & 35,30 & 10,81 \\
\hline
\end{tabular}

The results of physical or color testing of tubers found the highest L (brightness) value from $D$. bulbifera $\mathrm{L}$. with a value of 73.64 and followed by $D$. pentaphylla L. At 69.55 ; D. alata L. At 68.41 and D. hispida Dennst. at 67.59. On the other hand, D. alata L. bulbs showed the highest a (red colour) value of 4.53 followed by $D$. bulbifera L. at 1.96; and D. pentaphylla L. at 0.78 ; and $D$. hispida Dennst with the lowest a value of -2.02 indicating the the green color of tubers. The highest value of $b$ (yellow colour) was found at $D$. hispida Dennst. at 34.04 followed by $D$. bulbifera L. at $23.25 ; D$. alata L. at 9,30; and $D$. pentaphylla $\mathrm{L}$. at 5.50 . The highest total color difference $(\Delta \mathrm{E})$ was performed by $D$. bulbifera $\mathrm{L}$. at 77.75 and followed by $D$. hispida Dennst. At $75.70 ; D$. alata L. at 69.99; and D. pentaphylla L. at 69.86 .

Chemical analyses consist of proximate analysis, fiber content and HCN content. Moisture content of Dioscorea spp tubers were variated between $76.43 \%$ to $85.69 \%$ higher than $69.5 \%$ to $80.2 \%$ [12] but still in the interval of $71.06 \%$ to $92.48 \%$ [13]; $76.36 \%$ to $92.01 \%$ [14]; and $69.7 \%$ to $87.0 \%$ [15]. The tubers with lower water content could be stored for a long time and more efficiently processed on an industrial scale [16].

Tuber ash content varied between $0.62 \%$ to $1.02 \%$ which are very low compared to $2.60 \%$ to $6.36 \%$ [14] and $2.48 \%$ 
to $8.50 \%$ [13 but still corresponds to $0.5 \%$ to $1.2 \%$ [12] and $0.35 \%$ to $1.23 \%$ [15]. While the fat content based on fresh weight was $0.13 \%$ to $0.14 \%$ which are lower than $0.2 \%$ to $0.3 \%[12]$.

Protein levels of $1.57 \%$ to $3.85 \%$ corresponds to $1.6 \%$ to $3.1 \%$ based on fresh weight [12] [12] and are very low compared to $6.48 \%$ to $13.42 \%$ based on dry weight [14]; $5.25 \%$ to $15.75 \%$ [14] and $8.13 \%$ to $15.07 \%$ [15].

Carbohydrates content based on fresh weight was found variated between $11.86 \%$ to $19.48 \%$, lower than $17.4 \%$ to $25.9 \%$ [12]. Crude Fiber content were $0.43 \%$ to $1.28 \%$, lower compared to $0.6 \%$ to $1.5 \%$ based on fresh weight [12]; $3.48 \%$ to $7.69 \%$ based on dry weight [14]; $3.21 \%$ to $9.23 \%$ [13]; $1.62 \%$ to $6.88 \%$ [15]; and $0.67 \%$ to $1.50 \%$ [17].

The content of Cyanide Acid ( $\mathrm{HCN}$ ) based on fresh weight were $10.81 \mathrm{ppm}$ to $39.80 \mathrm{ppm}$ which are very high compared to $3.2 \mathrm{mg} . \mathrm{kg}^{-1}$ to $6.0 \mathrm{mg} . \mathrm{kg}^{-1}$ (Bhandari, MR and Kawabata, J., 2004); and $49.70 \mathrm{mg}^{-100 \mathrm{~g}^{-1}}$ to 79.40 $\mathrm{mg} .100 \mathrm{~g}^{-1}$ [18]. However, the high content of HCN can be reduced/eliminated by processing it before consumption by washing after peeling the tuber, soaking it with water for 9 hours or soaking it in sodium bicarbonate solution for 9 hours or cooked it for 90 minutes or steaming it at $121^{\circ} \mathrm{C}$ with a pressure of $15 \mathrm{lbs}$. [13]; tubers then cut into thin slices and soaked in salt water for 3 days, after which they are put in sacks and soaked in running water for 3 days by the Redang Island community, Malaysia [19]; thinly cut and boiled for two days by communities of Papua New Guinea [20] and boiled with wood ash for a long time by the Sakai tribe, Thailand [21].

The variations of the tubers physical characteristics consist of the value of brightness level (L), red (a), b (yellow), and the total color difference (maupunE) as well as variations in the chemical characteristics of the tuber namely the proximate composition, fiber content and $\mathrm{HCN}$ content of the four yam plant species (Dioscorea spp.) explorated from Manokwari Regency are related to genetics, soil fertility, location, and age of plants [22]; genetic differences [17].

\section{CONCLUSION}

The physicochemical characterization of tubers from four yam species plants explorated in the Manokwari Regency region showed variations influenced by genetic differences, soil fertility, location, and age of plants.

\section{REFERENCES}

[1] Acevedo-Rodriguez, P., 2005. Family Dioscoreaceae. In: Vines and Climbing Plants of Puerto Rico and the Virgin Islands. Smithsonian
Institution. Contributions from the United States National Herbarium, Vol.51: 421-427.

[2] Acevedo-Rodrguez, P., and Strong, M.T, 2005. Family 10. Dioscoreaceae Yam Family. In: Monocotyledons and Gymnosperms of Puerto Rico and the Virgin Islands. Contributions from the United States National Herbarium, Vol.52: 82-92.

[3] Coursey, D.G., 1967. Yams: An Account of the Nature, Origins, Cultivation and Utilization of the Useful Members of the Dioscoreaceae. London: Longmans, Greens and Co. Ltd.

[4] Hahn, S.K., 1995. "Yams, Dioscorea spp. (Dioscoreaceae)," In Evolution of Crops Plants, eds J. Smartt and N.W. Simmonds (London: Longman Group Limited), 112-120.

[5] Alexander, J., and Coursey, D.G., 1969. "The origins of yam cultivation," in The Domestication and Exploitation of Plants and animals. Proceedings of a Meeting of the Research Seminar in Archaeology and Related Subjects Held at the Institute of Archaeology, London University, eds P.J. Ucko and G.H. Dimbleby (Gerald: Duckworth \& Co. Ltd.),405425.

[6] Srivastava, A.K., Gaiser, T., 2008. Biomass production and partitioning pattern of Yam (Dioscorea rotundata). Agric. J. 3: 334-337.

[7] Jayakody, L., Hoover, R., Liu, Q., Donner, E., 2007. Studies on tuber starches. II. Molecular structure, composition and physicochemical properties of yam (Dioscorea sp.) starches grown in Sri Lanka. Carbohydrate Polymers, 69(1), pp.148-163. Elsevier.

[8] Liu, Q., Donner, E., Yin, Y., Huang, R.L. and Fan, M.Z. 2006. The physicochemical propertiesand in vitro digestibility of selected cereals, tubers, and legumes grown in China. Food Chemistry 99: 470-477.

[9] Schoeninger, M.J., Bunn, H.T., Murray, S.S., and Marlett, J.A. 2000. Compotition of tubers used by Hadza foragers of Tanzania. Journal of Food Compotition and Analysis, 13, 1-11.

[10] Rasulu, H., Yuwono, S.S. and Kusnadi, J., 2012. Characteristics of fermented cassava flour as material for producing sagukasbi. Jurnal Teknologi Pertanian, 13(1).

[11] Rasulu, H., Quality Improvement of Cassava Flour of Local Variety of Ternate Through Fermentation Method (Application on Traditional Food of North Maluku "Sagu Lempeng"). International Journal on Advanced Science, Engineering and Information Technology, 4(6), pp.423-425. 
[12] Bhandari, M.R., Kawabata, J., Kasai, T., 2003. Nutritional Evaluation of Wild Yam (Dioscorea spp.) Tubers of Nepal. Food Chemistry, 82: 619623. Elsevier.

[13] Shanthakumari, S., Mohan, V.R., and John de Britto. 2008. Nuritional Evaluation and Elimination of Toxic Principles in Wild Yam (Dioscorea spp.). Tropical and Subtropical Agroecosystems, 8: 319-325.

[14] Shajeela, P.S., Mohan, V.R., Jesudas, L.L., and Soris, P.T. 2011. Nutritional and Antinutritional Evaluation of Wild Yam (Dioscorea spp.). Tropical and Subtropical Agroecosystems, 14: 723-730.

[15] Huang, C.C., Chiang, P.Y., Chen, Y.Y., and Wang, C.C.R. 2007. Chemical compositions and enzyme activity changes occurring in yam (Dioscorea alata L.) tubers during growth. Science Direct, LWT 40: 1498-1506. Elsevier.

[16] Polycarp, D., Afoakwa, E.O., Budu, A.S., and Otoo, E. 2012. Characterization of chemical composition and anti-nutritional factors in seven species within the Ghanaian yam (Dioscorea) germplasm. International Food Research Journal, 19 (3): 985-992.

[17] Wu, Z-G., W. Jiang, M. Nitin, X-Q Bao, S-L Chen and Z-M Tao, 2016. Characterizing Diversity Based on Nutritional and Bioactive Compositions of Yam Gerplasm (Dioscorea spp.) Commonly Cultivated in China. Journal of Food and Drug Analysis 24: 367-375.

[18] Anhwange, B.A., Asemave, K., Ikyenge, B.A., and Oklo, D.A., 2011. Hydrogen Cyanide Content of Manihort Utilissima, Colocasia Esculenta, Dioscorea Bulbifera and Dioscorea Domentorum Tubers Found in Benue State. International Journal of Chemistry. Vol.3, No. 4: 69-71.

[19] Nashriyah, M., Athiqah, M.Y.N., Amin, H.S., Norhayati, N., Azhar, A.W.M., Khairil, M., 2011. Ethnobotany and Distribution of Wild Edible Tubers in Pulau Redang and Nearby Islands of Terengganu, Malaysia. International Journal of Nutrition and Food Engineering. 5(12): 911-914.

[20] French, B.R., 2006. Root Crops and Starchy Staple Foods. In: Food Plants of Papua New Guinea. A compendium Revised edition. Pp.2332.

[21] Maneenoon, K., Sirirugsa, P., and Sridith, K., 2008. Ethnobotany of Dioscorea L. (Dioscoreaceae), a Major Food Plant of the Sakai Tribe at Banthad Range, Peninsular Thailand.
Journal of Plant, People and Applied Research, vol 6: pp. 385-394.

[22] Bhandari, M.R., and J. Kawabata, 2004. Assessment of antinutritional factors and bioavailability of calcium and zinc in wild yam (Dioscorea spp.) tubers of Nepal. Food Chemistry, 85: 281-287. Elsevier. 